\title{
ANAESTHESIA FOR INFANTS IN A COMMUNITY HOSPITAL*
}

\section{A. NEKUS, M.D.**}

THE practice of Anaesthesia in a community hospital requ res great versatility from the anaesthetist. He must possess the ability to deal wit. many special problems and provide efficient anaesthetic service for any patient admitted for an operation. Many of his patients will be infants, often in poor physical condition, requiring immedrate surgery. Knowledge of basic principles of physiology peculiar to this age group will help to provide satisfactory and safe anaesthesia.

The disproportion and weakness of structures interfere with infants' respiratory activity. There is an increased tendency towards respiratory obstruction due to a narrow airway, a large tongue, actively secreting mucus glands, as well as an out of proportion and _eary head, and a very short neck. Weak muscles are unable to expand sufficiently an unstable and elastic infant's chest; a bulky and possibly distended abdomen, on the other hand, may interfere with diaphragmatic excursions. A relatively srnall alveolar surface and a large dead space further decreases the efficiency of ventilation. The tidal volume of a premature infant may be as low as 5 ccs. This does not represent the volume of gas actually entering and leaving the alveolar air, for a portion of it lodges in the dead space. The metabolic rate, in infants, is very high and requires a large oxygen supply. The small tidal volume is compensated by a rapid respiratory rate.

Infants brought in for emergency surgery, who have been seriously ill, are frequently dehydrated or malnourished. Poor fluid intake, increased demand for fluids or excessive flud loss due to fever, vomiting or diarrhoea, may seriously disturb fluid and electrolyte balance. Acidosis may be pronounced, and ketone bodies may appear in the urne. Pre-operative correction of electrolyte imbalance, particularly if ketonuria is present, may be required.

Minor degrees of flutdand electrolyte imbalance though are common in sick children and there is little point in attempting to correct it pre-operatively.

An infant with a high fever, subjected to surgery and anaesthesia, most certainly will develop a high pulse rate, collapse and convulsions, especially during the hot summer months. $50 \mathrm{mgms}$. of Aspirin rectally, antibiotics and sponging of the body with cold water, or alcohol, will bring the temperature below $102^{\circ} \mathrm{F}$. per rectum. If convulsions do occur, intravenous injection of a barbiturate (Nembutal) will give diamatic results.

Traumatic cases and infants suffering from surgical or medical conditions associated with blood loss, when the Hgb reading is below 10 gms. should be transfused before the anaesthesia is commenced. In non-dehydrated infants, transfusion with packed cells is more satisfactory. The oxpgen carrying capacity will be increased with less danger of over-hydrating tre baby with a large volume of blood and over-loading it with sodium chloride. If a bottle of citrated

"Presented at a meetng of the Ontario Division, C.A.S, Ottawa, April 3, 1954.

"From the Department of Anaesthesia, Hôtel Dieu Hospital, Kingston, Ontario. 
blood is hung up on an i.v. post for a period of 3 to 4 hours, the blood cells, if not disturbed, will settle down. The lower part, containing cells, may be administered as packed cells.

\section{Pre-operative Feeding and Medication}

Infants are usually fed every four hours. Witholding of feedings depletes infants' glycogen stores and fasting for longer than four hours, pre-operatively, may be dangerous. Clear fluids (sweetened water or juice) may be given four hours pre-operatively to infants NOT suffering from bowel or pyloric obstruction-the possibilities of vomitng are slight. On the other hand, infants with bowel obstruction may require emptying of their stomach and parenteral administration of glucose.

Every infant, regardless of age and its physical condition, must be given, preoperatively, Atropine or Scopolamine-the suggested dose being 1/600 of a grain. Infants weighing 15 pounds and over may be given sedation, as well. The rate of absorption of subcutaneously injected drugs, in an ill and dehydrated patient, is unpredıctable. In this respect, the intramuscular administration of premedication is preferable. To all newborn babies, Vitamin " $K$ " must be given pre-operatively.

\section{Choice of an Anaesthetic Agent}

As a rule, it is stated that any anaesthetic agent that has been used safely in adults can be employed in children. Although one cannot pass by without discouraging the use, in infants, of potent anaesthetic agents, such as Chloroform or Ethyl Chloride. A narrow margin of infant safety is further narrowed by the potency of the agent.

Ether is stll considered one of the safest anaesthetic agents However, if large amounts of Ether, as in deep anaesthesia over prolonged period of time, are used, the liver function may become impaired, glycogenolysis increased, and excessive production of lactic acid may lead towards metabolic acidosis.

Cyclopropane and Nitrous Oxide have very little effect on the metabolism. The former requires the use of a closed system. Its use with a non-rebreathing technique, throughout the operation, is too expensive and, therefore, impractical; on the other hand, if Cyclopropane is used just for short periods of time for induction or when rapid deepening of anaesthesia is required, it may be very valuable. Nitrous Oxide if used with sufficient amounts of Oxygen requires to be supplemented by another anaesthetic agent, in order to produce satisfactory anaesthesia.

It seems that the idea of so-called "balanced anaesthesia", using two or more different agents, each in a relatively small quantity, is a preferential choice when dealing with an infant.

\section{Techniques and Methods}

Whatever the choice of an anaesthetic agent might be, the more important factor for a safe and successful anaesthesia is he way the drug is administered. If care is taken to observe basic principles, a baby may be expected to withstand the surgery for a considerable length of time. 
1. Adequate Oxygenation: An infa:at depends on its oxygen supjly from one inspiration to another and has no oxyzen reserve available in the jody.

2. Elimination of $\mathrm{CO}_{2}$ : Even smal increase in $\mathrm{CO}_{2}$ tension will lead to serious disturbance in infant's physiology, and acidosis will be produced ra sidly.

3. Reduction of Dead Space: A baby will make no effort to overcone excessive dead space for any length of time. Hypercapnia may be the result of rebreathing from a dead space approxımating the tidal volume in size. The smallest mask may increase the total dead space considerably in infants. Most avarlable anaesthetic equipment is out of proportion to infants' tidal volume.

4. Minimum Resistance: A respiratory fatigue, during anaesthesia, must be avolded at all costs, in infants. An araesthetic machine with all its valves, long tubing and resistance created by the $\mathrm{CO}_{2}$ absorber, is more than an infant can withstand

5 As Light a Plane of Anaesthesia as compatible with Surgery: It is said that an infant is less sensitive to a painful stimulus than adults. Since the margin of safety in babies is narrower, a lighter plane of anaesthesia will increase the safety.

The stages of anaesthesia in unfants are more dufficult to differentiate than in adults. Eye signs are unreliable, and so are the respirations-rapid and often irregular

Infants betray light anaesthesia by flexion of their elbows and clenching their fists The last is a very valuable guide in assessing the depth of anaesthesia.

The plane of anaesthesia just beyond the stage of "clenched fist"-some call it a "grasp reflex"-is sufficiently deep even for abdominal surgery in babies. Arms placed in a manner allowing the anciesthetist to see patient's hand, in spite of surgical draping, wll enable hum to guide the depth of anaesthesia accordingly. As long as the "grasp reflex" is preser.t that is, as long as the baby is clenching the fist, anaesthesia is deepened untıl the fists relax. From here on, the same depth of anaesthesia is carried throughout the operation.

Muscular relaxation is difficult to obtain mantaining a light plane of anaesthesia. Since infants' respirations primarly are of a diaphragmatic nature, "pushing" of the bowel through the abdominal incision is difficult to prevent, even under deep anaesthesia. Decreasing or abolishing the motions of the diaphragm by controlled respirations may remedy the "pushing".

A variety of techniques and methods is used to administer anaesthetics to infants. Some of these require complicated and expensive equipment. Simplicity of techniques and equipment in a small hospital is most valuable. It eliminates mechanical defects as well as expense.

One should remember, though, that no anaesthetic should be started on a baby unless: (a) oxygen with minurum equipment necessary to administer it, (b) a proper size airway, (c) a lary igoscope, (d) an infant size endotracheal tube, and (e) a suction apparatus are on hand, regardless of how simple the technique or how short the anaesthesia is going to be.

The Open Drop Technique has the advantage of simplicity, and provides good anaesthesia. Nevertheless, the danger of hypoxia and $\mathrm{CO}_{2}$ accumulation is nct eliminated, especially when using a heavy covered mask. Such a mask, when we; 
creates considerable resistance and increases the total dead space. The use of towel wrapping around the mask and face is not permissible in infants. Oxygen introduced under the mask at a flow rate of 500 to $10010 \mathrm{ccs} . / \mathrm{min}$. will improve the oxygenation and mechanically remove accumulating $\mathrm{CO}_{2}$.

When dealing with a very small or a very sick and toxic baby with embarrassed respirations, endotracheal anaesthesia should be chosen. The advantages of an endotracheal tube are worth the possible hazards associated with its use. An endotracheal tube: (a) provides a mechanically patent airway and overcomes the possibly increased resistance due to partially obstructed airway; (b) reduces considerably the dead space, since the tube dispenses with nasal and oral pharynx as well as the mask, and therefore lessens the danger of $\mathrm{CO}_{2}$ accumulation; (c) facilitates the removal of bronchial secretions; (d) facilitates the control of respirations, and (e) enables the anaesthetist to maintain a more even anaesthesia. Gentleness during intubation and the use of a proper size of endotracheal tube will decrease possible mechanical thauma and post-operative respiratory complications.

The ability of a "Portex" tube to mould at body temperature is advantageous and their use in infants is safer than that of rubber tubes. The size of the tube averages, in infants, between 13 to 18 French catheter size, depending on the size of the patient. Too small a tube will decrease the pulmonary ventilation and increase the resistance, while a too large tube will traumatize the larynx, the cords, and the trachea.

Anaesthesia facilitates the intubation, although an attempt to intubate under a light anaesthesia will be most certainly associated with a severe laryngospasm or coughing and "bucking" on the tube. A deep plane of anaesthesia is essential when intu jating.

In some instances, the condition of the infant brought in for an emergency operation may not permit the anaesthetist to reach: the required depth of anaesthesia before intubatıng. If the respurations are markedly embarrassed, whether due to interference with respiratory movements or respiratory obstruction, the patient is invariably suffermn from hypoxia. Immediate establishment of a clear airway and oxygenation $0^{-}$the baby should be considered lifesaving. The same applies to very ill and toxic infants. Those cases have to be intubated while awake. Gentleness of this procedure is of a paramount importance.

The technique of anaesthesia following an intubation depends largely on the available equipment. When an anaesthetic machine is available-I am sure almost every hospital has one-the anaesthetist has a wide choice of anaesthetic agents and techniques.

The use of $\mathrm{CO}_{2}$ absorption technique in infants requires continuous assistance of respirations and may lead to $\mathrm{CO}_{2}$ accumulation. The heat accumulation may be tremendous. A closed system anaesthesia requires an expert anaesthetist.

The non-rebreathing technique using a non-rebreathing valve, or a $\mathrm{Y}$ tube, are much simpler, require little equipment, and may be used with any tyse of anaesthetic machine. Both the $\mathrm{Y}$ tube and the non-rebreathing valve, if p-aced close to an endotracheal tube, reduce the dead space and the resistance to a 
minimum. They both provide means for artificial respirations. A non-rebreathing valve, such as Stephen-Slater valve, is superior to a $\mathrm{Y}$ tube. Assisted and controlled respirations can be carried out more satisfactorily without the danger of exposing the infant to a high intrapulmonary pressure.

Almost any anaesthetic agent may be used with both techniques. Nitrous Oxide with 25-30\% of Oxygen, supplemented with small amounts of Ether, seems to be preferred by most.

\section{General Considerations and Supportive Therapy}

A close watch of the tiny Jatient throughout the operation is just as important as a proper anaesthetic tecınique.

Surgical draping of the patient prevents seeing the respiratory movements of the chest and the abdomen. The movements of the bag are hardly noticeable, due to a small tidal exchange and a high gas-flow. A small stethoscope taped to the chest will enable the anaesthetst to follow the heart and the respirations.

Infants' heat regulation is very poor. This creates a serious problem during hot summer months. The patient under the heavy surgical draping, in an operatingroom with room temperature over 80 degrees and a high relative humidity, if no precautions are taken, most probably will develop hyperthermia. An ice bag placed close to the patient's body, number of drapes reduced to a minimum, and sufficient hydration will help to maintain the body temperature below $302^{\circ} \mathrm{F}$.

Infants under anaesthesia are partcularly jrone to develop acidosis. The fluid exchange is very rapid and dehydration or slood loss may lead to shock with considerable speed. The younger the baby, the more these reactions become exaggerated. Fluid replacement therapy is essential during all emergency operations. A vein assured by a cut-down before the beginning of surgery will enable one to carry out satisfactory fluid replacement therapy and will make a blood transfusion possible, if a necessity arises. Blood loss in infants is more satisfactorily replaced with packed cells, as already mentioned.

In general, there is a tendency to give too much fluid when dealing with a small subject. The total amount of parenteral fluids given to an infant depends on its size and the degree of dehydration or the blood loss. The maximum total amount of fluds administered during an operation should not exceed 5 ccs. per Ib. of body weight. If actuve blood loss, due to the operation, is present, the total amount of administered fluds during the operation may be increased up to 10 ccs. per $\mathrm{lb}$. of body weight, including blood transfusion.

In order to achieve the desured results from the fluid therapy, one should nemember that $(a)$ the blood loss must be replaced at the time of its loss; (b) saline should be used to a minumum; $(c)$ the-rate of administration should be as slow as possible, and $(d)$ the fluids administered oyer a period of 24 hours should not amount to over 75 ces. per lb. of body weight.

\section{Post-Operative Care}

Only very fortunate hospitals have a post-anaesthetic Recovery Room. Theretore, as a rule, all infants following a general anaesthesia should remain in the operating-room, where suction apparatus, oxygen, etc. are available. If not 
contra-indicated, from the surgical point of view, a baby is best placed in a lateral position. Close watch of the patient, removal of secretions, vomitus, or other material, and maintenance of a patent airway are just as important during the recovery period.

Whenever the intubation is accompanied by a prolonged manipulation or trauma due to technical or other difficulties, serious post-operative respiratory complications may be lessened or avoided by placing the patient in a croupette for at least 24 hours post-operatively. If a croupette is not available, the same can be achreved by placing the child in a cooled oxygen tent. The required high humidity may be supplied by passing exygen through an Aerosol-Penicillin nebulizer, contnuously filling it with water.

In conclusion, it should be emphasized that infant's weak structures, its high metabolic rate, and its exaggerated reactions to stress, require at all times utmost gentleness, strict adherence to techniques and maintenance of anaesthesia assuring good pulmonary ventilation, least disturbance of infant's physiology, and a satisfactory fluid replacement therapy.

\section{SUMMARY}

The efficiency of ventilation in infants is poor, due to anatomical and physiological factors peculiar to that age group, while the oxygen demand is very large.

Further disturbance of infants' normal physiology by the disease, fever, dehydration, malnutrition, or anemia greatly increase the anaesthetic problem.

When preparing an infant for surgery, all the above mentioned should be taken into consideration.

In choosing the anaesthetic agent and technique of administration, one should take care to observe the following basic principles:

1. Adequate oxygenation

2. Elimination of $\mathrm{CO}_{2}$

3. Reduction of dead space

4. Minimum resistance

5. As light a plane of anaesthesia as compatible with surgery.

It is important to select the sumplest possible technique which meets all of these requirements. Endotracheal anaesthesia offers certain advantages, and it should be chosen when dealing with very small or very sick children undergoing major surgery. Gentleness and equipment of proper size is very important when intubating an infant. The use of non-rebreathing technique by means of a nonrebreathing valve or a $\mathrm{Y}$ tube is advocated.

A close watch of the small patient and adequate fluid replacement theraวy throughout the operation cannot be over-emphasized. In order to prevent tue danger of over-hydration, the limits for the amount of fluids administered parenterally is laid down to $5 \mathrm{ccs}$. per lb. of body weight, plus the replacement of actual blood loss during operation.

A close watch of the baby during recovery is a necessity and it is more satisfactorily done right in the operating-room, where the necessary equipment for possible emergencies is available. Following a complete recovery, the infant 
may be moved back to the ward. Cool and highly humid atmosphere, such as supplied by a crousetle, is recornmended for infants where post-operative respiratory complicat_ons may be expected.

\section{RÉSUMÉ}

L'efficacité de la ventilation chez les enfants est mauvaise à cause des facteurs anatomiques et physiologiques particuliers à cet âge, alors que l'exigence en oxygène est très grande.

D'autres désordres de la playsiologie normale de l'enfant occasionnés par la maladie, fièvre, déshydratation, alımentation défectueuse ou l'anémie auğmentent considérablement le problème anesthésique.

On devra tenir compte de tous les factenrs précités en préparant l'enfant pour l'intervention chirurgicale.

En choisissant l'agent anesthésique et la technique d'administration, on prendra soin d'observer les principes fondamentaux suivants: (1) une oxygénation adéquate; (2) l'élimination du $\mathrm{CO}_{2} ;$ (3) réduction de l'espace nuisible; (4) résistance minima; (5) un plan d'anesthésie aussi léger que possible et compatible avec l'intervention chirurgicale.

Il est important de choisir la technique la plus simple possible qui répond à toutes ces exigences. L'anesthésie endotrachéale offre certains avantages et sera préférée dans le cas d'enfants très jeunes ou très malades subissant des interventions chirurgicales majeures.

La douceur et un équipment de dimension approprié sont des facteurs très importants en pratiquant l'intubation de l'enfant. L'emploi de la technique du "non-rebreathing" par l'emploi de la valve appropriée ou d'un tube $\mathrm{Y}$ est conseillé.

On ne peut trop réitérer la nécessité d'une surveillance étroite du jeune pa ieht et une thérapeutique de remplacement du fluide pendant l'opération. 'our éviter le danger de l'excès d'hydratation, les limites de la quantité de fluides admmistrés parentéralement sont fixées à 5 ccs. par livre du poids du corps, plus le remplacement de perte actuelle de sang pendant l'opération.

Une surveillance étroite du bébé pendant le rétablissement est essentielle et elle sera observée d'une façon plus satisfaisante dans la salle d'opération même, où l'on disposera de l'équipement nécessaire en vue d'accidents possibles. Après le rétablissement complet on pourra ramener l'enfant dans la salle d'hôpital. Un air froid et très humide comme celui que fournit une croupette, est recommandé pour les enfants dans les cas où l'on peut s'attendre à des complications respiratoires à la suite de l'opération.

\section{REFERENCES}

1. Stephen, C R C M.A J. 63. 109-112 1950.

2. Gross, R E The Surgery of Infancy and Childhood. 1953

3. Dix, G W. Bulletun of the Hospital for Sick Children, in Toronto $242-441953$.

4. Stephen, C R. and Slater, H M. Paper presented at Fall Meetng of the Montreal MedChi Society October 21, 1948

5 Stephen, C $R$ and Stater, H M Curr Res Anes. and Anal. 29, 254-262. Sept.-Oct. 1950. 
6. Stephen, C. R. and St.ATER, H. M. C.M.A. . 64: 22-26 1951.

7. Slater, H. M. and Stephen, C. R. Arch. o Surg.: 62: 251-259: 1951.

8. Stephen, C. R. and Slater, H. M Conn. State Med. J. XIII: 109: August, 1949.

9. Stephen, C. R. Arch. of Surgery: 60: 1035-1044: June, L950.

10. Stephen, C. R. and Slater, H. M. Anaesthesiology: 9: 550-552: September, 1948.

11. Harris, T. A. B. The Mode of Action of Anaesthetics: 475-619, 1951.

12. Slater, H. M. and Ferguson, R. H. Pamphlet-Children's Memonal Hospital, Montreal: 1953.

13. Ferguson, R. H. Children's Memorial Hospital- Personal Communications 